\title{
Seismic Waves Response Characteristics of Niger Delta Soils
}

\author{
Okovido, J. O. ${ }^{1}$ and Kennedy, C. ${ }^{2}$ \\ ${ }^{1,2}$ Department of Civil Engineering, University of Benin, Benin City, Nigeria \\ Corresponding Author: *johnokovido@uniben.edu
}

https://doi.org/10.36263/nijest.2021.01.0255

\begin{abstract}
The study investigated the dynamic soil properties of States in Niger Delta region of Nigeria as a function of seismic activities. The down-hole seismic test was used to determine the response of the soils. The results of soil samples collected up to $30 \mathrm{~m}$ depth, showed that the average young modulus increases with increase in depth, which ranged from $115.77 \pm 1.74$ to $3231.17 \pm 1.01 \mathrm{kPa}$ across the States. Also, shear wave velocity generally increases with increase in depth. The average shear wave velocity across the States ranged from $126.00 \pm 1.86$ to $288.00 \pm 2.63 \mathrm{~m} / \mathrm{s}$. Also, the average $P$-wave velocity increases with depth, with values across the States ranging from $310.60 \pm 3.51$ to $656.00 \pm 3.69 \mathrm{~m} / \mathrm{s}$. On the other hand, the void ratio was observed to be constant at certain range of depth, and in most with values across the States ranging from $0.651 \pm 093$ to $0.860 \pm 067$. Unlike void ratio, Poisson's ratio fluctuates with depth, with values across the States ranging from $0.23 \pm 2.27$ to $0.36 \pm 1.18$. Based on the results, the Niger Delta region may be resistant to earthquake, but as an oil hub of Nigeria, it is also susceptible to earthquake that could be triggered by stress due to heavy load and seismic activities.
\end{abstract}

Keywords: Seismic activities, Soil dynamic response, Niger Delta region

\subsection{Introduction}

Globally, natural disasters have become a great challenge to humans. These disasters ranged from the failures of embankments, natural slopes, earth structures and foundations; and they have been attributed to the liquefaction of sands, landslides and slope instability (Ige et al., 2016). However, these natural disasters are a result of seismic effects and only occur in a geographical area with distinct characteristics. The geotechnical seismic response is a function of intense motion due to the stress-strain response of soils. The parameters of soil mechanical properties of damping ratio (D), shear modulus $(\mathrm{G})$, shear wave velocity (Vs) and Poisson's ratio are those connected with dynamic loading.

The wave generated due to earthquakes developed vibrations in the ground and create severe natural disasters which are functions of regional seismicity, nature of the source of mechanism, geology, and local soil conditions. Seismic activities of a natural or induced earthquake or earth tremor, tsunami, flood, cyclone liquefaction, and landslide cause extensive damages to the environments, roads, buildings, bridges, ports, life-line, oil and gas infrastructures and loss of life. Earthquake or earth tremor is the trembling or shaking of the ground resulting from the unexpected or startling release of energy within the earth. Its activities result from accumulated stresses within the outer $700 \mathrm{Km}$ shell of the earth (Osagie, 2008).

Historical and notable earthquakes or earth tremors in Nigeria were compiled and documented from journals, personal communications with the natives of the associated areas and newspapers written from 1933 - 2016. These developments in the nations' geological history bring to the question of agelong belief that Nigeria is seismically safe and not prone to earthquakes. The possible mechanisms for these intraplate tremors could be due to the regional stress created by the West African Craton (Adepelumi et al., 2008). In homogeneities and zones of weakness in the crust created by the various episodes of magmatic intrusions and other tectonic activities also were considered as sources of seismicity in Nigeria. Two assumptions and theories were considered as the possible basis of the seismicity in the country, the possible faults systems were inferred based on the spatial distribution of 
the earth tremors in Yola- Dambata, Akka-Jushi, and Warri - Ijebu Remo systems (Afegbua, 2011). Most of these fault systems are trending northwest-southeast. The second was affirmed that earlier theory revealed that the tremors occurred in the inland extension of the northeast- southwest originating from the Atlantic Ocean and that possibly causes the activities along the Ijebu-Ode and Ibadan axis which is inferred to be associated with the Ifewara- Zungeru fracture systems (Adepelumi et al., 2008).

Some earth tremor reviewed and documented in Nigeria is of southern origin, (Osagie, 2008; Akpan and Yakubu, 2010). The areas which have experienced ground motion include Lagos, Ibadan and IleIfe on 22nd June 1939. On the same day, the event was recorded in Accra (Ananaba, 1991); IjebuOde on 21st December, 1963 (Ajakaiye et al., 1987); Ibadan, Ijebu-Ode, Shagamu and Abeokuta on 28th July and 2nd August, 1984 (Ajakaiye et al., 1987); Ibadan and Ijebu-Ode on 27th June, 1990 (Ananaba, 1991; Ojo, 1995 and Osagie, 2008); Okitipupa in 1997 (Odeyemi, 2006), Okitipupa, Ibadan, Ijebu-Ode, Akure, Shagamu, Abeokuta and Oyo on 7th March, 2000 (Elueze, 2003; Odeyemi, 2006; Akpan and Yakubu, 2010). Tremors were also felt in other parts of the country, Gembu and Jalingo on 16th October 1982, Yola on 8th December 1984 and March 2005 (Akpan and Yakubu, 2010), Kombani Yaya in present-day Gombe State between 18th to 19th June 1985 (Ugodulunwa et al., 1986; Ajakaiye et al., 1988). Dan Gulbi near Gusau in Zamfara State on November 7, 1994, witness some ground motion caused by an earthquake of local magnitude 4.2 (Akpan and Yakubu, 2010). Lupma near Minna in Niger State also experienced ground motion on 25th March 2006 (Akpan and Yakubu, 2010). Historical earthquakes or earth tremors in Nigeria were compiled from journals, personal communications with the natives of the associated areas and newspapers written from 1933 -2016. The intensities of these events ranged from III to VI based on the Modified Mercalli Intensity Scale. Therefore, this study investigates the dynamic soil properties of Niger Delta region of Nigeria as a function of seismic parameters.

\subsection{Materials and Methods}

\subsection{Sample location}

The soil samples were collected from four (4) States of the Niger Delta Region of Nigeria. The sampling locations are in Rivers State (Akinima and Mbiama Towns in Ahoada West Local Government, Ogbogu Town in Ogba/Egbema/Ndoni Local Government Area, Tombia Town in Degema Local Government Area and Bori Town in Khana Local Government Area; Bayelsa State (Igbogene and Agudama Towns in Yenagoa Local Government Area, Otuasega Town in Ogbia Local Government Area and Nembe Town in Nembe Local Government Area), Akwa-Ibom State (Ikot Abasi Town in Ikot Abasi Local Government Area, Ibagwa Town in Abak Local Government Area and Ibiaku Offot Town in Uyo Local Government Area) and Delta State (Aboh Town and Afor Ogbodigbo Town in Ndokwa East Local Government Area).

\subsection{Soil sample collection}

All soil samples were collected by subsurface exploration activities at the sites which included drilling and deep boring by standard penetration test (SPT). In-situ field test and laboratory test were adopted in this research work. The tests were conducted to estimate the dynamic soil properties. The soil samples were dried, crushed and sieved on sieve No. $4(4.75 \mathrm{~mm})$ with standard and known weights taken, mixed with amount water which represented natural water content state. Soil samples were remolded to field density and natural moisture content stage. Samples were prepared with specimen standard measurements of $20 \mathrm{~mm}$ height and $70 \mathrm{~mm}$ diameter, placed in membrane of rubber, mounted on bottom plate of cyclic direct simple shear machine of confined rings of control lateral deformation at consolidation stages.

\subsection{Seismic bore-hole test}

This test enables characterization of lithologic and ground water flow conditions than cuttings, split spoon samples, or core samples alone in a more detailed manner. The borehole technique has an advantage in that it can describe subsurface conditions in greater detail than surface-based methods. By the cross-hole seismic (CS) measurements, the dynamic elastic moduli including shear modulus, Young's modulus, and Poisson's ratio can be determined. This is a field test in which bore holes are installed and instrumented to measure the wave propagation velocity. 
The shear wave velocity and $p$-wave velocity were determined using the down-hole seismic (DS) test method, which uses a hammer source at the surface to impact a wood plank and then generate shear and compressing waves. This is typically accomplished by coupling a plank to the ground near the borehole and then impacting the plank in the vertical and horizontal directions. The energy from these impacts is then received by a pair of matching three component geophone receivers, which have been lowered in the down hole and are spaced at $1.5 \mathrm{~m}$ to $3 \mathrm{~m}$ apart.

\subsection{Results and Discussion}

The seismic down-hole dynamic soil properties of the various locations in Niger Delta region of Nigeria was studied based on young modulus, shear wave velocity, $p$-wave velocity, void ratio and Poisson's ratio.

\subsection{Variation of Young modulus}

The Young modulus, as an important material property essential for the evaluation of soil dynamic response, was studied and compared across the five States of the Niger Delta region represented in Figure 1. Thus, the average young modulus increased with increase in the sampling depth. Though, the behavior of young modulus in sites located in Rivers State showed high fluctuating characteristics compared to sites in the other States. However, from analysis, the numerical values of the average young modulus obtained from sites located in Rivers State ranged from 156.96 $\pm 2.18-3231.17 \pm 1.01$ $\mathrm{kPa}$, while others ranged from $118.17 \pm 3.37-2809.21 \pm 2.51 \mathrm{kPa}$ for Bayelsa State, $119.81 \pm 1.13-$ $2769.53 \pm 0.46 \mathrm{kPa}$ for Akwa Ibom State and 115.77 $\pm 1.74-2900.25 \pm 2.09 \mathrm{kPa}$ for Delta State. Although, at initial and final soil depth of $30 \mathrm{~m}$, the values of young modulus recorded across the soil layers as depth increases was highest in Bayelsa State followed by Akwa-Ibom, Delta and Rivers State. Despite the variations, the average young modulus across the States is not significantly different. Therefore, it can be said that the soil dynamic response of States in the Niger Delta region of Nigeria, based on the young modulus analysis, are interwoven.

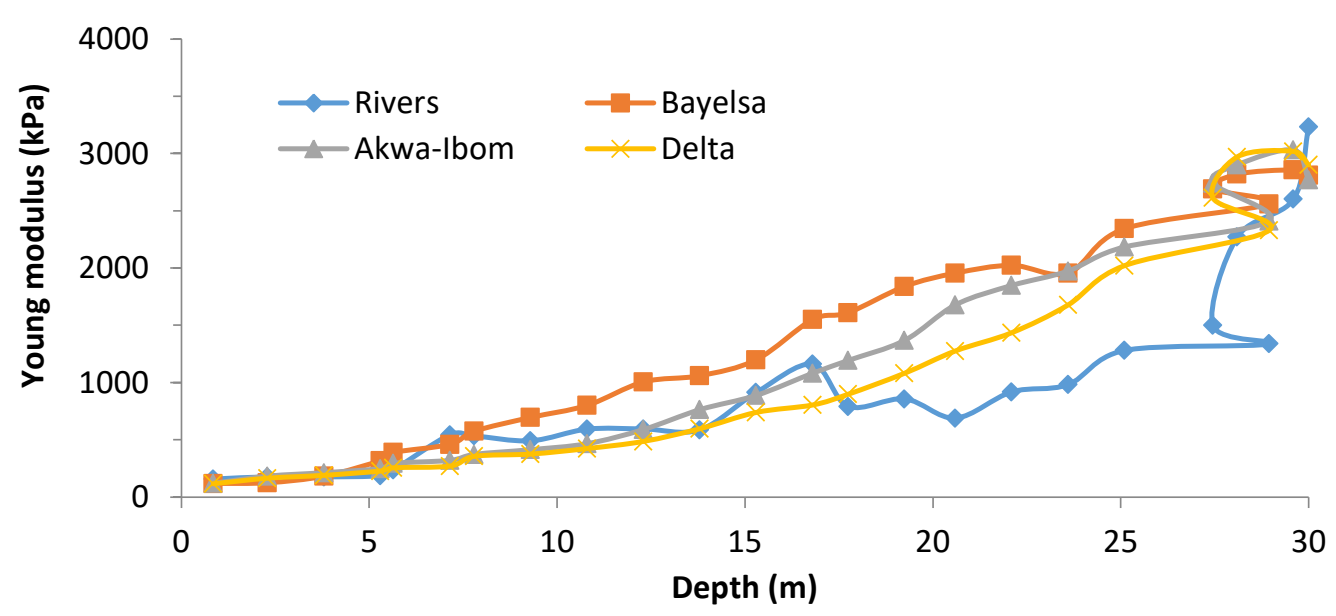

Figure 1: Variation of young modulus across the States

\subsection{Variation of shear wave velocity}

Figure 2 shows the profiles of the variability in shear wave velocity in Niger Delta soils. This property is important for characterization of vibration effect that often resulted in earthquake or tremor. Although this situation, especially earthquake, has not been recorded in this region, but there is potential for its occurrence in the future due to the continuous exploitation of crude oil and gas. The determination of shear wave velocity in soil makes the measurement of soil stiffness easy to determine (Viggiani and Atkinson, 1995). Hence, the soils' analysis revealed that shear wave velocity generally increase with increase in soil depth. The average shear wave velocity results obtained from the sites across the State ranged from $128.30 \pm 1.78$ to $288.00 \pm 2.63 \mathrm{~m} / \mathrm{s}, 130.00 \pm 0.56$ to $253.67 \pm 1.09 \mathrm{~m} / \mathrm{s}, 136.67 \pm$ to $264.00 \pm 3.01 \mathrm{~m} / \mathrm{s}$ and $126.00 \pm 1.86$ to $275.00 \pm 1.42 \mathrm{~m} / \mathrm{s}$ Rivers, Bayelsa, Akwa Ibom and Delta States respectively. Again, the ranges of shear wave velocity recorded across the Niger Delta States show no much variation. Hence, the shear wave velocity results have further shown that the Niger Delta region of Nigeria shares a similar soil dynamic response. 


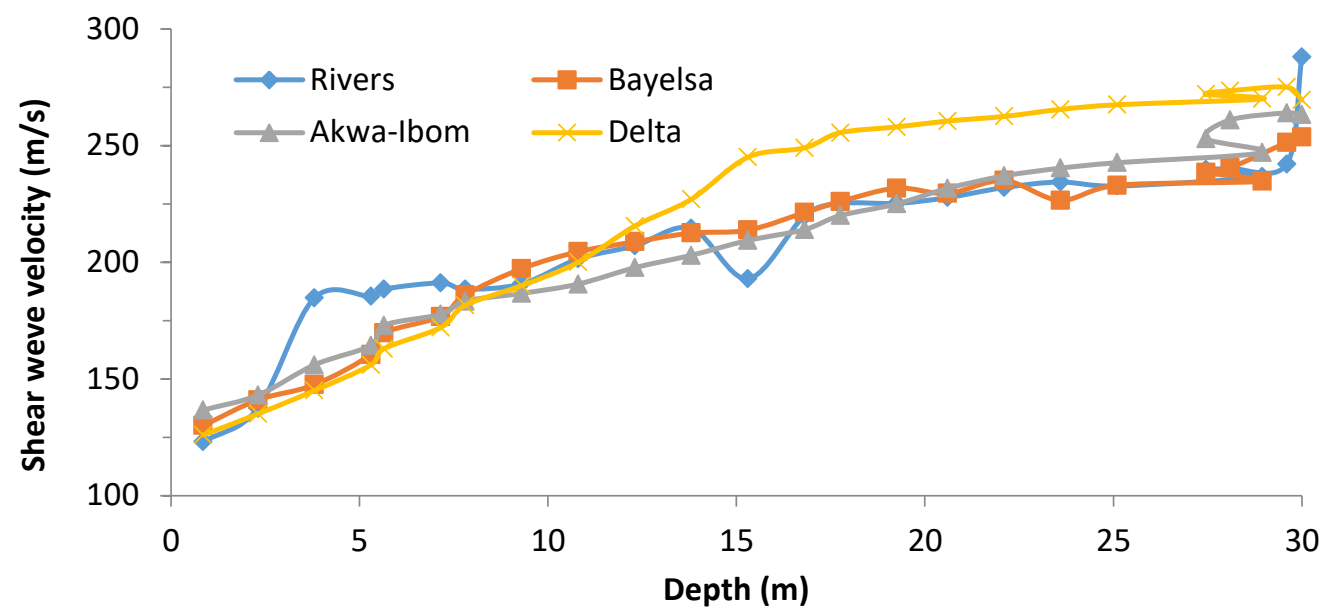

Figure 2: Variation of shear wave velocity across the States

\subsection{Variation of $P$-wave velocity}

Figure 3 showed the profiles of $p$-wave velocity investigated between 0.85 to $30 \mathrm{~m}$ soil depth across site locations. Like the shear wave velocity, $p$-wave velocity generally increases with increase in soil depth in all the investigated sites. Meanwhile, the magnitude of $p$-wave velocity recorded is over twice the values of shear wave. However, as shown in Figure 3, the average $p$-wave velocity recorded in Delta is slightly higher than those obtained from other States, especially beyond 15 meters depth, with values ranging from $325.50 \pm 3.02-649.50 \pm 1.32 \mathrm{~m} / \mathrm{s}$, while the average values of $p$-wave velocity recorded in the other States ranged from $310.60 \pm 3.51-595.00 \pm 0.77 \mathrm{~m} / \mathrm{s}, 327.25 \pm 2.10-579.25 \pm 3.04 \mathrm{~m} / \mathrm{s}$ and $345.67 \pm 2.11-656.00 \pm 3.69 \mathrm{~m} / \mathrm{s}$ respectively. Like shear wave velocity, the average $p$-wave velocity in the Niger Delta States is not significantly different.

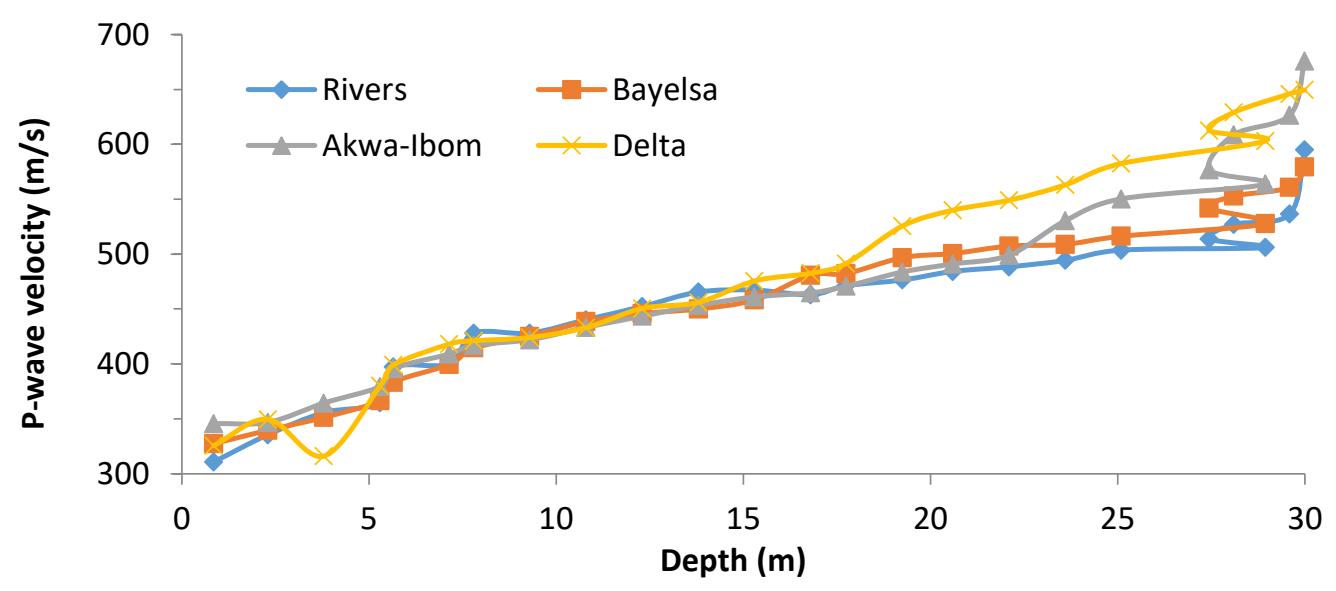

Figure 3: Variation of $p$-wave velocity across the States

\subsection{Variation of void ratio}

Figure 4 shows the profiles of the average void ratio of the respective States obtained across site locations. The void ratio was observed to be constant at certain range of depth in the soil strata, and in most cases, it does not increase correspondingly with depth. These circumstances arose due to soil characteristics, primarily due to particles size distribution across the soil strata. The ranges of average void ratio results obtained from the States are recorded as $0.672 \pm 1.001-0.860 \pm .067,0.651 \pm 0.093$ $0.751 \pm 0.115,0.700 \pm 2.134-0.804 \pm 1.071$ and $0.670 \pm 1.404-0.801 \pm 0.833$ for Rivers, Bayelsa, AkwaIbom and Delta States respectively. Again, there is high proximity of void ratio values of soils in the different States, which at some sites, it cannot be vividly differentiated.

It has been established that larger void ratio may reduce the dynamic shear modulus and shear wave velocity of soil, and as well, the natural frequency (vibration) of soil due to earthquake load (Panuska and Frankovska, 2016; Munirwansyah et al., 2020). Therefore, it can be inferred from the range of void ratio recorded that Niger Delta soil may be resistant to earthquake. 


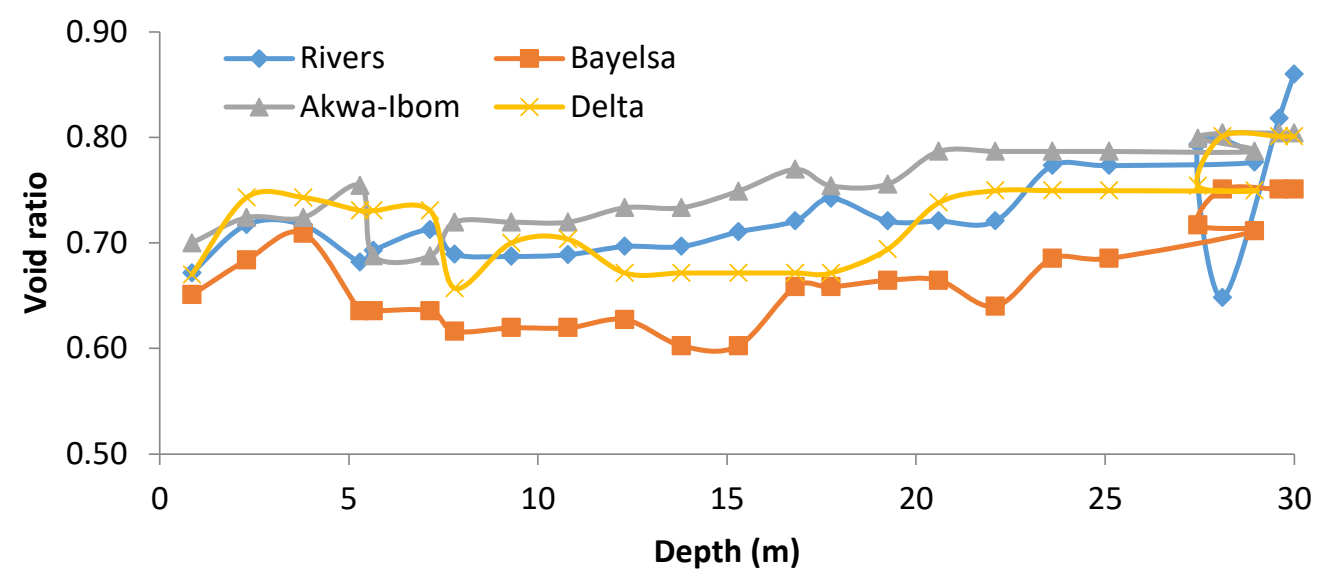

Figure 4: Variation of void ratio across the States

\subsection{Variation of Poisson's ratio}

Figure 5 showed the profiles of average Poisson's ratio obtained from the sites locations in the various States. Unlike void ratio, Poisson's ratio was observed to be highly fluctuating with depth. The fluctuations can be attributed to soil characteristics properties. From the figure, it can be seen that Bayelsa State recorded the least average Poisson's ratio, while it was relatively highest in Delta State at some soil depth. The average Poisson's ratio obtained from sites located across the States ranged from $0.25 \pm 1.04-0.35 \pm 2.09$ for Rivers State, $0.23 \pm 2.27-0.33 \pm 1.14$ for Bayelsa State, $0.27 \pm 0.92$ $0.35 \pm 2.20$ for Akwa Ibom State, and $0.25 \pm 1.48-0.36 \pm 1.18$ for Delta State.

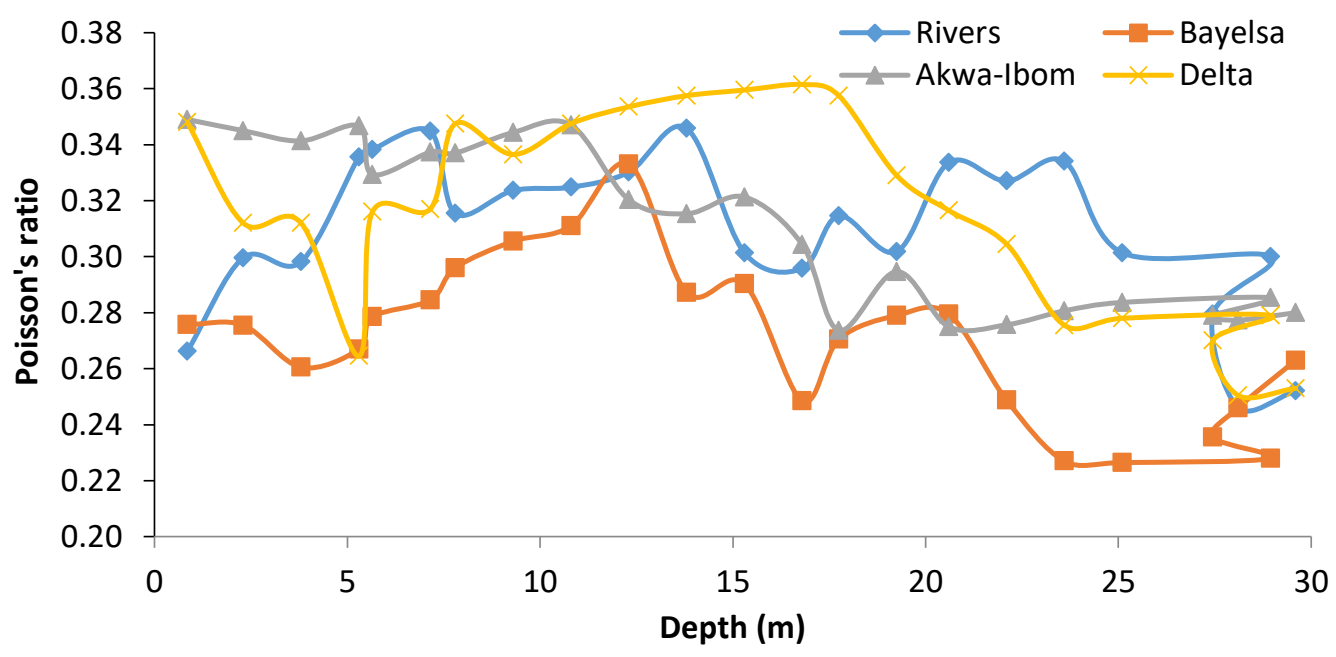

Figure 5: Variation of Poisson's ratio across the States

\subsection{Conclusion}

The seismic dynamic soil properties of the various sites across the States of Niger Delta region based on analysis of young modulus, shear wave velocity, $p$-wave velocity, void ratio and Poisson's ratio showed no significant different in the soil dynamic properties within the region. In addition, the young modulus, shear wave velocity and $p$-wave velocity, generally increased with soil depth, while the void ratio was constant at certain range in the soil layers. These circumstances were due to particles size distribution across the soil strata. Also, there was high fluctuation in Poisson's ratio as soil depth was increased. However, based on results of some of the dynamic soil properties, it can be concluded that the Niger Delta region may be resistant to earthquake, but as an oil hub of Nigeria, it is also susceptible to earthquake that could be triggered with time if over stressed by heavy load and seismic activities. 


\section{References}

Adepelumi, A. A., Ako, B. D., Ajayi, T. R., Olorunfemi, A.O., Awoyemi, M. O. and Falebita, D. E. (2008). Integrated geophysical mapping of the Ifewara transcurrent fault system, Nigeria. Journal of African Earth Sciences, 52(4-5), pp. 161-166.

Ajakaiye, D. E., Daniyan, M. A., Ojo, S. B. and Onuoha, K. M. (1987). The July 28, 1984 southwestern Nigeria evolution of Nigeria. Journal of Geodynamics, 7, pp. 205-214.

Ajakaiye, D. E., Hall D. H., Millar, T. W., Verheijen, P. J., Awad, M. B. and Ojo, S. B. (1988). Aeromagnetic Anomalies Trough, Nigeria. Nature, 319, pp. 582-584.

Akpan, O. U. and Yakubu, A. Y. (2010). Earthquake Science, 23, pp. 289-294.

Ananaba, S. E. (1991). Dam sites and crustal mega lineaments in Nigeria. ITC J., 1, pp. 26-29.

Elueze, A. A. (2003). Evaluation of the 7 March 2000 earth tremor in Ibadan area, southwestern Nigeria. Jour. of Min. and Geol., 39(2), pp. 79-83.

Ige, O.O., Oyeleke, T. A., Baiyegunhi, C. and Oloniniyi, T. L. (2016). Liquefaction, Landslide and Slope Stability Analyses of Soils: A Case Study of Soils from Part of Kwara, Kogi and Anambra States of Nigeria, Natural Hazards Earth System Science Discussions. Available at: http://www.doi:10.5194/nhess-2016-297, July 24, 2018.

Munirwansyah, M., Munirwan, R.P., Listia, V., Munirwan H. and Melinda, Z. (2020). Void ratio effect on dynamic shear modulus and shear wave velocity for soil stiffness in Banda Aceh and Aceh Besar, Journal of Physics: Conference Series. Retrieved from: https://doi:10.1088/1742$\underline{6596 / 1572 / 1 / 012090}$

Odeyemi, I. B. (2006). The Ifewara fault in Southwestern Nigeria: Its relationship with fracture zones along the Nigerian Coast. Lecture delivered at the Centre for Geodesy and Geodynamics, Toro, Bauchi State. 13p.

Ojo, O. M. (1995). Survey of occurrences in Nigeria of natural and man-made hazards related to geological processes. In: Onuoha K M and Offodile M E (eds.), Proceedings of the International workshop on natural and man-made hazards in Africa, Awka, Nigeria, pp. 10- 14.

Osagie, E.O. (2008). Seismic activity in Nigeria, Pacific Journal of Science Tech., 9(2), pp. 1-6.

Panuska, J. and Frankovska, J. (2016). Effect of void ratio on the small strain shear modulus for coarse-grained soils. Procedia Engineering, 161, pp. 1235-1238.

Ugodulunwa, F. X. O., Ajakaiye, D. E., Guiraud, M. and Hossan, M. T. (1986). The Pindiga and Obi fractures-possible earthquake sites in Nigeria. In: Proceedings of the 3rd International Conference on current research in geophysics and geophysical research in Africa, Jos, Nigeria, 6p.

Viggiani, G. and Atkinson, J. H. (1995). Interpretation of Bender Element Tests. Geotechnique, 45(1), pp. 149-154. 